DOI: $10.20472 / B M .2020 .8 .2 .006$

\title{
A PILOT STUDY OF THE HONG KONG SMARTPHONE MARKET: HOW SERVICE QUALITY AFFECTS REPURCHASE INTENTION VIA CUSTOMER SATISFACTION AND ATTITUDINAL LOYALTY
}

\author{
HOLLY NG, TILO LI, MARINE YEUNG
}

\begin{abstract}
:
The smartphone penetration rate among people aged 15 and above in Hong Kong stood at close to 90 per cent in 2018. While the demand for smartphones has been increasing, the smartphone market in Hong Kong is highly competitive. Smartphone firms strive to maintain their customers by encouraging repurchases through launching newer models. The marketing cost of keeping an existing customer is well below that of finding a new customer. Therefore, how to motivate current customers to repurchase newer editions of the same brand is a major marketing concern for most companies. The purpose of this paper is to explore the causality between service quality and repurchase intention via customer satisfaction and attitudinal loyalty. Data from a sample of 200 Hong Kong smartphone users aged 18 and above confirm that customer satisfaction mediates the relationship between service quality and attitudinal loyalty that eventually affects repurchase intention. The percentage of the direct effect of service quality on attitudinal loyalty demonstrated a significant partial mediation of customer satisfaction. The results of this study provide important theoretical and managerial implications for researchers and practitioners of the smartphone industry not only in Hong Kong but also around the world.
\end{abstract}

\section{Keywords:}

Smartphone marketing, service quality, customer satisfaction, attitudinal loyalty, repurchase intention

JEL Classification: D12, M31

\section{Authors:}

HOLLY NG, Tung Wah College, Hong Kong, Email: hollyng@twc.edu.hk

TILO LI, Tung Wah College, Hong Kong, Email: tiloli@twc.edu.hk

MARINE YEUNG, Tung Wah College, Hong Kong, Email: marineyeung@twc.edu.hk

\section{Citation:}

HOLLY NG, TILO LI, MARINE YEUNG (2020). A pilot study of the Hong Kong smartphone market: How service quality affects repurchase intention via customer satisfaction and attitudinal loyalty. International Journal of Business and Management, Vol. VIII(2), pp. 93-109., 10.20472/BM.2020.8.2.006 


\section{Introduction}

The first-generation mobile phone manufactured by Motorola decades ago was heavy and expensive. It only had the function of a telephone. With the emersion of smartphone, the firstgeneration portable mobile phones are now mocked as the "dump" phone.

In around the year of 2000, Sharp launched the world's first camera mobile phone, and BlackBerry launched the world's first mobile phone that supported emails and web-browsing. These add-ons to mobile phones started the severe race in the market. Portable mobile phone manufacturers had to change from producing "dump" phones to "smart" phones.

In the early development of mobile phones, the major world players were Motorola, Nokia, Siemens, Sony Ericsson, Sharp, and BlackBerry. Apple's iPhone 2 launched in May 2007 totally changed the landscape of the smartphone market. These early day players have mostly been replaced by Samsung, Huawei, Apple, Xiaomi, vivo, and OPPO.

In the smartphone market any manufacturer unable to catchup with the latest technology and new add-on functions will be competed away. As such, the ability to incorporate the latest technology with attractive and useful functions on new models to retain existing customers is crucial to continuous survival for smartphone manufacturers. Incidentally, in the highly competitive wireless telecommunications industry, a firm's customer acquisition cost is more sensitive to market-share position and competition than its customer retention cost. In other words, customer retention cost is less dependent on competition than customer acquisition cost. As competition increases, customer acquisition cost can exceed four times of the customer retention cost, which is quite stable across different competition levels (Min, et al., 2016). Other researchers have estimated that it costs five times more in acquiring new customers than in retaining existing customers (Chen \& Myagmarsuren, 2011; Ofori, Boakye, \& Narteh, 2018).

In view of the substantially lower customer retention cost than customer acquisition cost, the purpose of this study is to examine the effect of service quality on customer satisfaction that in turn affects customer's attitudinal loyalty, and how attitudinal loyalty leads to repurchase intention. The research questions are:

1. Is the relationship between service quality and customer satisfaction positive and statistically significant?

2. Is there a mediating effect of customer satisfaction on the relationship between service quality and attitudinal loyalty?

3. How does attitudinal loyalty influence repurchase intention?

In the next section, the smartphone market in Hong Kong will be briefly discussed, followed by a review of relevant literature and discussion of the conceptual constructs. After these, the research methodology, results, and conclusion will be presented.

\section{The Smartphone Market}

Mobile phones emerged in Hong Kong and became popular for non-business users in the early 1990s. According to statistics released by the Hong Kong Special Administrative Region 
("HKSAR") Government (HKSAR, 2019), in 2018, 89.3 per cent of the population, totaling 5.59 million people aged 15 and above had a smartphone. The smartphone penetration rate of the HKSAR was ranked second in the world, after South Korea in 2018 (Holst, 2019b).

In 2018, smartphone shipments totaled 1.4 billion units worldwide (Holst, 2019a). The shipments are expected to increase to 1.49 billion units in 2023 (International Data Corporation, Dec 2019). According to International Data Corporation (Jan 13, 2020), the world shipments of used smartphones were 175.8 million units in 2018. The figure is expected to reach 332.9 million units in 2023, a compounded annual growth rate of 13.6 per cent. These figures imply that 332.9 million current smartphone users will repurchase newer smartphones with more advanced technology.

As of the first quarter of 2019, major smartphone brands in the world smartphone market were Samsung (23.1\%), Huawei (19.0\%), Apple (11.7\%), Xiaomi (8.0\%), vivo (7.5\%), and OPPO (7.4\%) (International Data Corporation, Jan 13, 2020) in descending order with respect to their market shares shown in corresponding brackets. However, in Hong Kong, Apple and Samsung are the most popular brands. It is expected that with the $5 \mathrm{G}$ technology built-in on Huawei smartphones, Huawei will capture more market share. Rivalry competition among smartphone manufacturers is becoming increasingly severe. To maintain or capture more market share, firms must retain their current customers in addition to acquiring new ones. The following section will review the theoretical base of service quality, customer satisfaction, attitudinal loyalty and repurchase intention of customers.

\section{Service Quality, Customer Satisfaction, Attitudinal Loyalty and Repurchase Intention}

Attitudinal loyalty refers to the extent of customers' emotional or psychological attachment to a brand (Rauyruen \& Miller, 2007). Since smartphones are constant companions to most people in their daily life, it is very easy for them to build emotional attachment to their smartphones (Lam \& Shankar, 2014). When customers feel emotionally attached to a brand, attitudinal loyalty to the brand is developed. Customers having developed attitudinal loyalty towards a particular brand will develop behavioral loyalty to the brand, and they will have high resistance to switching to another brand. Attitudinally loyal customers will keep buying the same brand even when no incentive is offered. This is consistent to human behavior that most people are reluctant, if not resistant to changes. As a result, these customers are more profitable to the companies. Because of the importance and relevance of attitudinal loyalty to the smartphone market, this study focuses on attitudinal loyalty when developing a framework that would enable further understanding of the factors underlying brand loyalty.

Research has demonstrated that service quality can lead directly to loyalty because high service quality creates value for customers (Ahmed, et al., 2011). Service quality is especially important when competitors offer similar product quality; customers use service quality to differentiate among competitors (Srivastava \& Sharma, 2013). While it is reasonable to expect service quality helps organizations develop customer loyalty, studies have also found that service quality does not necessarily directly build loyalty. It may build customer loyalty through customer satisfaction (Solimun \& Fernandes, 2018; Yadav \& Rai, 2019). Before attitudinal loyalty can be developed, customers need to have feelings of satisfaction derived from the 
service quality. This means that customer satisfaction mediates the relationship between service quality and attitudinal loyalty as satisfied customers are likely to keep using the same phone brand (Lee, et al., 2015). However, the relationship between customer satisfaction and customer loyalty may also not be a straightforward one. Some studies suggest that customer satisfaction is an important antecedent for attitudinal loyalty (Rauyruen \& Miller, 2007; RusselBennett, McColl-Kennedy, \& Coote, 2007), but others argue that customer satisfaction is insufficient for the development of brand loyalty (Agustin \& Singh, 2005).

As shown above, different conclusions have been drawn on the relationship between service quality and attitudinal loyalty, with some suggesting a rather direct causal relationship between the two and others highlighting customer satisfaction as a mediating factor. The interplay of these factors is of high relevance to the smartphone industry as service quality is particularly important in the smartphone industry (Tseng \& Lo, 2011), where customers need a great deal of personal services to help them resolve technical problems with the devices. Above all, service is a tool to increase differentiation controllable by competing companies (Sharma \& Singh, 2012; Srivastava \& Sharma, 2013). Responsiveness, reliability and assurance are considered important in smartphone services because they can affect customer satisfaction and in turn affect customer loyalty (Shin, 2014, 2015). These elements are in line with the wellknown service quality framework SERVQUAL, developed by Parasuraman, Zeithaml and Berry (1988).

In addition to the relationship between customer satisfaction and customer loyalty, the link between customer loyalty and actual purchase behavior also needs further investigation. Attitudinal loyalty has been considered as a leading factor of repurchase intention (Aydin \& Ozer, 2005), which in turn has been examined separately and considered to be a strong predictor of actual purchase behavior because it directly drives the actual repurchase behavior (Akhter, 2010; Lin \& Liang, 2011). Given the significant role of repurchase intention in determining repurchase behaviour, it is useful to incorporate it in the equation of customer retention and understand how it is derived from attitudinal loyalty.

The factors identified above have been explored in various previous studies. For example, brand loyalty has been found to be the most important factor considered by customers when they purchase a smartphone (Muhammad, Hamad \& Shabir, 2014); emotional attachment was indicated by 84 per cent of iPhone users as the reason for their intention to buy an iPhone again in a survey carried out by the market research firm GfK, (GfK, November 2011). However, these studies each focuses on one individual factor in explaining repurchase behavior without capturing the cascading relationships among the various factors of service quality, customer satisfaction, attitudinal loyalty, and repurchase intention as discussed above. Considering the relevance of these factors to the smartphone market, this study set out to verify the relationships among them in the context of the Hong Kong smartphone market. This study aims to evaluate whether service quality can, through customer satisfaction, influence attitudinal loyalty and subsequently repurchase intention.

\section{Methodology}

The aim of this study is to examine the effect of service quality on attitudinal loyalty through the mediation of consumer satisfaction, and how repurchase intention is influenced by attitudinal loyalty in the Hong Kong smartphone market. A deductive-based quantitative 
research approach was chosen due to the exploratory nature of the study. The study focused on the causality effects among the identified variables: service quality, customer satisfaction, attitudinal loyalty, and repurchase intention.

This study used standard and mediated regression analysis to explain the variance in the dependent variables. An anonymous questionnaire survey was conducted with a sample of 200 ( $N=200$ ) Hong Kong smartphone users aged 18 and above. This sample size was considered to be adequate as according to Sekaran and Bougie (2019), the sample size is preferably at least 10 times as large as the number of variables. Therefore, the minimum sample size for this study was 40 .

The subjects of the study were conveniently available and thus convenience sampling was adopted for the study. An online survey was used to obtain the sample, and the participants were recruited through online discussion forums opened at facebook.com and discuss.com.hk for smartphone users. Many smartphone users use online discussion forums to share and search for information about smartphones. Smartphone users with such online behavior allowed themselves to be sampled for this online survey. Because the study focused on the Hong Kong smartphone market, the inclusion criteria for participants were (1) Hong Kong residents, (2) aged 18 and above, and (3) current smartphone users.

The participants were invited to complete an online questionnaire (Appendix A). The questionnaire contained 21 questions developed for the assessment of the four variables on a seven-point Likert-scale ( 1 = strongly disagree; 7 = strongly agree). Questions 1 to 8 in the questionnaire (Appendix A) were used to assess service quality; questions 9 to 13 were for customer satisfaction; questions 14 to 19 for attitudinal loyalty; and questions 20 and 21 for repurchase intention.

A link to the invitation page was provided on the forum page where participants were recruited. To verify whether the potential respondents fulfilled the inclusion criteria, three screening questions about their residence, age and whether they were using smartphones were posted together with the invitation. Respondents who did not meet the inclusion criteria received a message notifying them of their ineligibility and thanking them for their interest in the study. To encourage respondents to complete the entire questionnaire, a progress indicator was displayed for each respondent to show how far the respondent had progressed through the questionnaire at particular points.

Inter-item consistency reliability tests were conducted to assess the consistency of respondents' answers to all the items used in the study because all variables were measured with multi-item scales. Cronbach's coefficient alpha was used to measure reliability as it is an adequate index of inter-item consistency reliability in most cases (Sekaran \& Bougie, 2019).

Confirmatory factor analysis was conducted to test the extent to which the a priori, theoretical pattern of factor loadings on the constructs was held before further analysis of the actual data by means of standard and mediated regression. 


\section{Results}

A total of $200(N=200)$ valid online responses were received. The frequency and percentage of demographic variables describing the sample are presented in Table 1.

Table 1: Demographics of the respondents

\begin{tabular}{|c|c|c|c|}
\hline \multirow{2}{*}{\multicolumn{2}{|c|}{ Demographic variables }} & \multicolumn{2}{|c|}{ Valid sample $\mathbf{N}=200$} \\
\hline & & \multirow{2}{*}{\begin{tabular}{|l|} 
Frequency \\
200 \\
\end{tabular}} & \multirow{2}{*}{$\begin{array}{l}\% \\
100\end{array}$} \\
\hline Residency & Hong Kong & & \\
\hline \multirow[t]{5}{*}{ Age } & $18-24$ & 29 & 14.5 \\
\hline & $25-34$ & 40 & 20.0 \\
\hline & $35-44$ & 53 & 26.5 \\
\hline & $45-54$ & 52 & 26.0 \\
\hline & $55-64$ & 26 & 13.0 \\
\hline \multirow[t]{2}{*}{ Gender } & Male & 112 & 56.0 \\
\hline & Female & 88 & 44.0 \\
\hline \multirow[t]{4}{*}{ Education } & College & 30 & 15.0 \\
\hline & Degree & 114 & 57.0 \\
\hline & Master or above & 50 & 25.0 \\
\hline & Secondary or below & 6 & 3.0 \\
\hline \multirow[t]{6}{*}{ Income } & $\$ 10,000$ or below & 16 & 8.0 \\
\hline & $\$ 10,001-\$ 20,000$ & 28 & 14.0 \\
\hline & $\$ 20,001-\$ 30,000$ & 23 & 11.5 \\
\hline & $\$ 30,001-\$ 50,000$ & 77 & 38.5 \\
\hline & $\$ 50,001-\$ 70,000$ & 24 & 12.0 \\
\hline & $\$ 70,001$ or above & 32 & 16.0 \\
\hline
\end{tabular}

More than half of the respondents (52.5 per cent) were between 35 and 54 years old. A majority of the respondents had a degree qualification or above (82 per cent), indicating that most of them were capable of judging the service quality provided by different smartphone brands and thus should be able to provide relevant feedback about their satisfaction with different smartphone brands. In terms of individual monthly income, a majority of the respondents (78 per cent) earned $\mathrm{HK} \$ 20,001$ or above. This indicates that it is financially viable for the respondents to buy expensive smartphone brands such as Apple's iPhone and Samsung's Galaxy. This finding is consistent with the proportion of respondents who have bought iPhone and Galaxy (80 per cent). Overall, the respondents' demographics indicate that many smartphone users are mature in age, relatively highly educated, and earning higher 
income. Their opinions should be reliable as they have the capability to judge the smartphone performance, and determine their satisfaction and loyalty level.

Table 2 indicates the distribution of the smartphone brands currently in use by the respondents. A majority of them use Apple (43.5 per cent) and Samsung ( 36.5 per cent) brands. The total share of all other brands is far below the share of either of these brands. This indicates that Apple and Samsung are the two most popular brands in Hong Kong, and their users are mainly high qualification and high-income groups.

Table 2: Current smartphone brand in use

\begin{tabular}{|l|l|l|}
\hline Smartphone brand in use & Frequency & $\%$ \\
\hline Apple (e.g. iPhone series) & 87 & 43.5 \\
Samsung (e.g. Galaxy series) & 73 & 36.5 \\
Sony (e.g. Xperia series) & 16 & 8.0 \\
HTC (e.g. 8XT/One/Droid DNA) & 5 & 2.5 \\
LG (e.g. Optimus/Lucid/Spectrum) & 9 & 4.5 \\
Motorola (e.g. Droid Ultra) & 3 & 1.5 \\
Nokia (e.g. Lumia series) & 2 & 1.0 \\
Sky Vega & 1 & 0.5 \\
Xiaomi & 4 & 2.0 \\
\hline
\end{tabular}

The Cronbach's alpha values are all above 0.90 indicating all measures used in the study are highly reliable. The Bartlett test of sphericity for all constructs show that the results of factor analysis are statistically significant $(p<0.001)$, indicating that the correlation matrix of each construct is not an identity matrix and has significant correlation among variables.

To answer the first two research questions, mediation testing was done by adopting the model developed by Baron and Kenny (1986). The model includes three steps: Step 1: conduct regression using attitudinal loyalty as the dependent variable and service quality as the independent variable; Step 2: conduct regression using customer satisfaction as the dependent variable and service quality as the independent variable; and Step 3: conduct regression using attitudinal loyalty as the dependent variable, and service quality and customer satisfaction as the independent variables. Regression results are shown in Table 3.

The results from steps one and two indicate that service quality has a significant positive effect on attitudinal loyalty $(\beta=0.930, p<0.001)$ and customer satisfaction $(\beta=0.875, p<0.001)$. This answers Research Question 1 that service quality and attitudinal loyalty, and service quality and customer satisfaction are positively related; and the positive relationship is statistically significant. 
Table 3: Regression Results for Mediation Testing

\begin{tabular}{|l|l|l|l|}
\hline Constant & R Square & Coefficient ( $\beta)$ & p-value \\
\hline $\begin{array}{l}\text { Step 1, attitudinal loyalty as dependent variable, service quality as independent } \\
\text { variable }\end{array}$ & 0.606 & 0.930 & 0.000 \\
\hline Service quality & 0.581 & 0.875 & 0.000 \\
\hline $\begin{array}{l}\text { Step 2, customer satisfaction as dependent variable, service quality as independent } \\
\text { variable }\end{array}$ & \begin{tabular}{l} 
Service quality \\
\hline $\begin{array}{l}\text { Step 3, attitudinal loyalty as dependent variable, service quality and customer } \\
\text { satisfaction as independent variables }\end{array}$
\end{tabular} \\
\hline $\begin{array}{l}\text { Service quality } \\
\text { Customer satisfaction }\end{array}$ & 0.766 & 0.645 & 0.000 \\
\hline
\end{tabular}

The third step is to regress attitudinal loyalty on both service quality and customer satisfaction. While the effect of customer satisfaction on attitudinal loyalty is significant $(\beta=0.645, p<$ $0.001)$, the effect of service quality on attitudinal loyalty remains significant $(\beta=0.366, p<$ 0.001 ) when customer satisfaction is controlled for. However, the effect of service quality on attitudinal loyalty is much less in Step $3(\beta=0.366)$ than in Step $1(\beta=0.930)$. After customer satisfaction is controlled for, the relationship between attitudinal loyalty and service quality is substantially reduced (from 0.930 to 0.366 ), but it is still significant. Thus, customer satisfaction has a partial mediation effect on the relationship between service quality and attitudinal loyalty. Partial mediation implies that not all loyal customers who are satisfied with the service quality have customer satisfaction.

Figure 1 illustrates the relevant statistical diagram with beta coefficients obtained for different steps for the calculation of the mediation effect. The mediation effect is 0.564 (c $-c^{\prime}=0.930$ $-0.366)$. The percentage of the direct effect that is being mediated is around 61 per cent, demonstrating a significant partial mediation. These results answer to Research Question 2 that there is a mediating effect of customer satisfaction on the relationship between service quality and attitudinal loyalty.

For Research Question 3 concerning how attitudinal loyalty affects repurchase intention, Table 4 summarizes the regression results.

Table 4: Regression results with repurchase intention as dependent variable

\begin{tabular}{|l|l|l|l|}
\hline Constant & R Square & Coefficient ( $\boldsymbol{\beta})$ & p-value \\
\hline Attitudinal loyalty & 0.509 & 0.713 & 0.000 \\
\hline
\end{tabular}

The results support that attitudinal loyalty has a high significant effect on repurchase intention $(\beta=0.713, p<0.001)$. The beta value indicates that attitudinal loyalty has a positive correlation with repurchase intention. As the attitudinal loyalty score increases, indicating improving 
attitudinal loyalty, the repurchase intention score will also increase, indicating improving repurchase intention.

Figure 1: Statistical diagram of the Mediation Testing

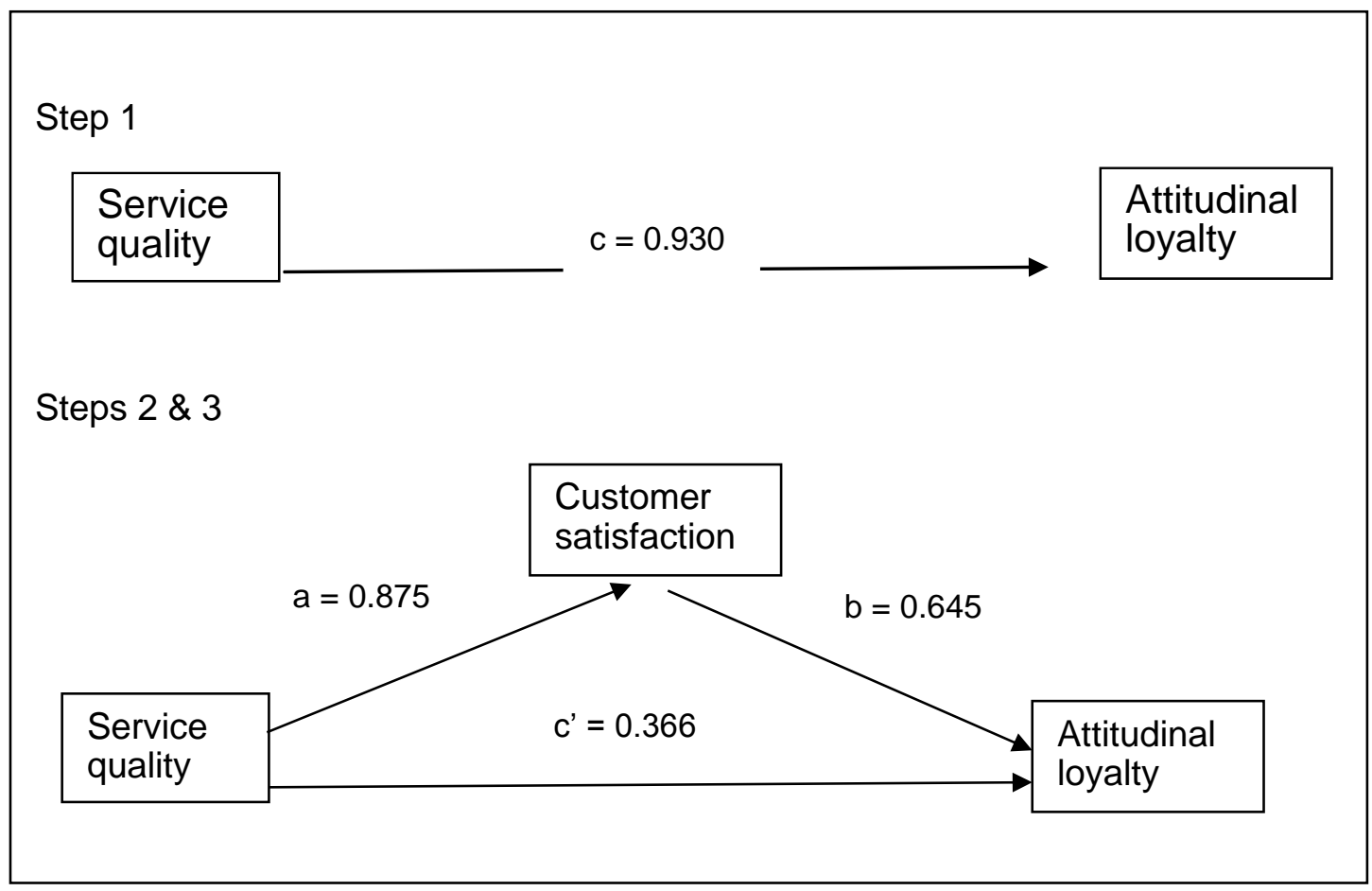

\section{Discussion}

The relationship between service quality and customer satisfaction is significant. This first research question is therefore answered. The positive beta coefficient indicates that the higher the service quality experienced by customers, the more the customers are satisfied with the brand. This finding is consistent with many prior studies, that service quality has a direct and significant effect on customer satisfaction (Ahmed, et al., 2010; Leonnard, 2018; Suhud \& Bajunaid, 2018), and it plays an important role in customer satisfaction (Wilson, et al., 2019).

Although the findings support only partial mediation, the partial mediating effect of customer satisfaction on the relationship between service quality and attitudinal loyalty is significant. Thus, the second research question is answered. Overall, the indirect effect of service quality on attitudinal loyalty stemmed from the positive correlation between service quality and customer satisfaction that directly affects attitudinal loyalty. The findings contradict some prior studies that suggest there is a direct relationship between service quality and attitudinal loyalty (Cöner \& Güngör, 2002). According to the results of this study, service quality has an indirect effect on attitudinal loyalty through customer satisfaction in the smartphone market. Such findings are consistent with previous studies conducted for other industries (Chang, et al., 2015; Diallo, et al., 2018; Narunart \& Panjakajornsak, 2019; Yadav \& Rai, 2019). Therefore, the findings of this study extend the conclusion on this relationship to the Hong Kong smartphone market. 
Partial mediation effect suggests that not all loyal customers who are satisfied with the service quality are satisfied with the smartphone brands they have used. Perhaps they are not satisfied with other aspects of the brand, for example, features and sizes, and thus they are not satisfied. However, since they are so satisfied with the quality of service provided by the brand, they become attitudinally loyal. Customer satisfaction is thus found to be very important in the smartphone market because of its direct effect on attitudinal loyalty, and its mediating role between service quality and attitudinal loyalty. This is consistent to research done for other service industries (Kasiri, et al., 2017).

The relationship between attitudinal loyalty and repurchase intention is found to be positively, significantly correlated. The finding echoes previous studies (Upamannyu, et al., 2015), that attitudinal loyalty has a positive and significant effect on behavioral intentions such as repurchase intention. This answers the third research question. When customers consider themselves loyal to a brand, and that the brand is their first and best choice, they have a high probability of repurchasing the same brand. This study confirms that attitudinal loyalty is the driver of repurchase intention in the Hong Kong smartphone market. This is consistent to some prior research of other industries (Hong \& Cho, 2011). However, attitudinal loyalty only explains 50.9 per cent of the variance in repurchase intention. This indicates that more variables should be included. As Prabowo, Astuti, and Respati (2020) suggest, word-of-mouth is a major factor for customers' repurchase intention. Besides, changes in income, taste and preferences, and peer influence can perhaps affect repurchase intention.

It is more profitable to retain existing customers than to acquire new ones (Ofori, Boakye, \& Narteh, 2018). Companies should continue to focus on factors that lead to customer loyalty and retention. Attitudinal loyalty and repurchase intention are important measures for customer loyalty and retention, which are crucial to a company's long-term business success and financial performance (Su \& Tong, 2016). For a company to achieve long-term success, it is essential that it understands the factors affecting attitudinal loyalty and repurchase intention and act on it accordingly.

\section{Conclusion}

To conclude, findings of this study have confirmed that, in the Hong Kong smartphone market, customer satisfaction plays a critical role in loyalty building. It directly builds attitudinal loyalty and mediates the relationship between service quality and attitudinal loyalty. Therefore, customer satisfaction is an important factor in loyalty building in the smartphone market. The findings also reveal that service quality is not a very strong direct predictor of attitudinal loyalty. However, service quality is important in building customer satisfaction so that attitudinal loyalty can be built. The study also clarifies the roles of attitudinal loyalty and repurchase intention by confirming that attitudinal loyalty is the driver of repurchase intention in the smartphone market.

With the findings of this study, smartphone manufacturers can gain insight into developing strategies that can help them achieve a higher level of attitudinal loyalty and repurchase intention. Product quality is certainly important. When manufacturers cannot differentiate their products with their rivals', they must gain an edge by providing comparatively higher-quality service for customers. To achieve this, customer-centered service strategies, communication strategies and training strategies are the main suggestions derived from the findings. 
Besides customer satisfaction, there is a need to identify other variables affecting attitudinal loyalty. Understanding the predictive effect of repurchase intention on actual repurchase behavior is certainly crucial. Considering the difficulties encountered in measuring actual purchase behavior, an 'intention' approach is adopted in this study rather than a behavioral one. Although some studies consider repurchase intention a strong predictor of actual purchase behavior (Keiningham, et al., 2007), there is a need to empirically test such correlation by evaluating the actual sales data of the companies. The sales data might include sales amount by customers, and purchase frequency and interval by customers. Unfortunately, owing to the limited resources of this study, it is not possible to obtain actual sales information from companies. To encourage companies to release their sales information, researchers need to convince them that the studies will help them realize their potential to enhance longterm performance by achieving competitive advantages.

For future research in the Hong Kong smartphone market concerning building attitudinal loyalty and purchase/repurchase intention, it is suggested that other antecedents such as brand trust and peer influence may be included. To triangulate quantitative results, focus group interviews can be conducted to not only verify quantitative data but also gain deeper understanding of factors to retain current customers through different antecedents. 


\section{APPENDIX A: Questionnaire}

\section{Section one}

The following questions are for classification. Please check or respond appropriately for each question.
a) Age: $\bigcirc$ below $18 \bigcirc_{18-24} \bigcirc_{25-34} \bigcirc_{35-44} \bigcirc_{45-54} \bigcirc_{55-64} \bigcirc_{65}$ or above
b) Are you a Hong Kong resident?
$\bigcirc$ Yes $\bigcirc$ No (your residency)
c) Are you a current smartphone user? ONo OYes

A smartphone is a mobile phone built on a mobile operating system, with more advanced computing capability and connectivity than a mobile phone. The smartphones combined the following functions with a mobile phone to form one multiuse device: personal digital assistant (PDA), portable media players, digital cameras, pocket video cameras, GPS navigation units, touchscreens and web browsers that display standard web pages as well as mobile-optimized sites.

\section{Section two}

d) Current smartphone brand in use:
Apple (e.g. iPhone series)
LG (e.g. Optimus/Lucid/Spectrum)
Sony (e.g. Xperia series)
Nokia (e.g. Lumia series)
Osamsung (e.g. Galaxy series)
OHTC (e.g. 8XT/One/Droid DNA)
OMotorola (e.g. Droid Ultra)
Others

\section{Please indicate your agreement or disagreement with the following questions regarding the experiences with the current smartphone brand you are using now.}

\begin{tabular}{|l|l|l|l|l|l|l|l|l|}
\hline \multicolumn{3}{|c|}{ Strongly Disagree } & \multicolumn{3}{|c|}{ Strongly Agree } \\
\hline \multicolumn{2}{|l|}{$\begin{array}{l}\text { When I have a problem, this brand shows a sincere interest in solving } \\
\text { it. }\end{array}$} & $\mathbf{1}$ & $\mathbf{2}$ & $\mathbf{3}$ & $\mathbf{4}$ & $\mathbf{5}$ & $\mathbf{6}$ & $\mathbf{7}$ \\
\hline 2 & This brand performs the service right the first time. & & & & \\
\hline 3 & Employees of this brand give me prompt service. & & & & & & \\
\hline 4 & Employees of this brand are never too busy to respond to my request. & & & & & & & \\
\hline 5 & Employees of this brand are consistently courteous. & & & & & & & \\
\hline 6 & Employees of this brand can answer my questions. & & & & & & \\
\hline
\end{tabular}




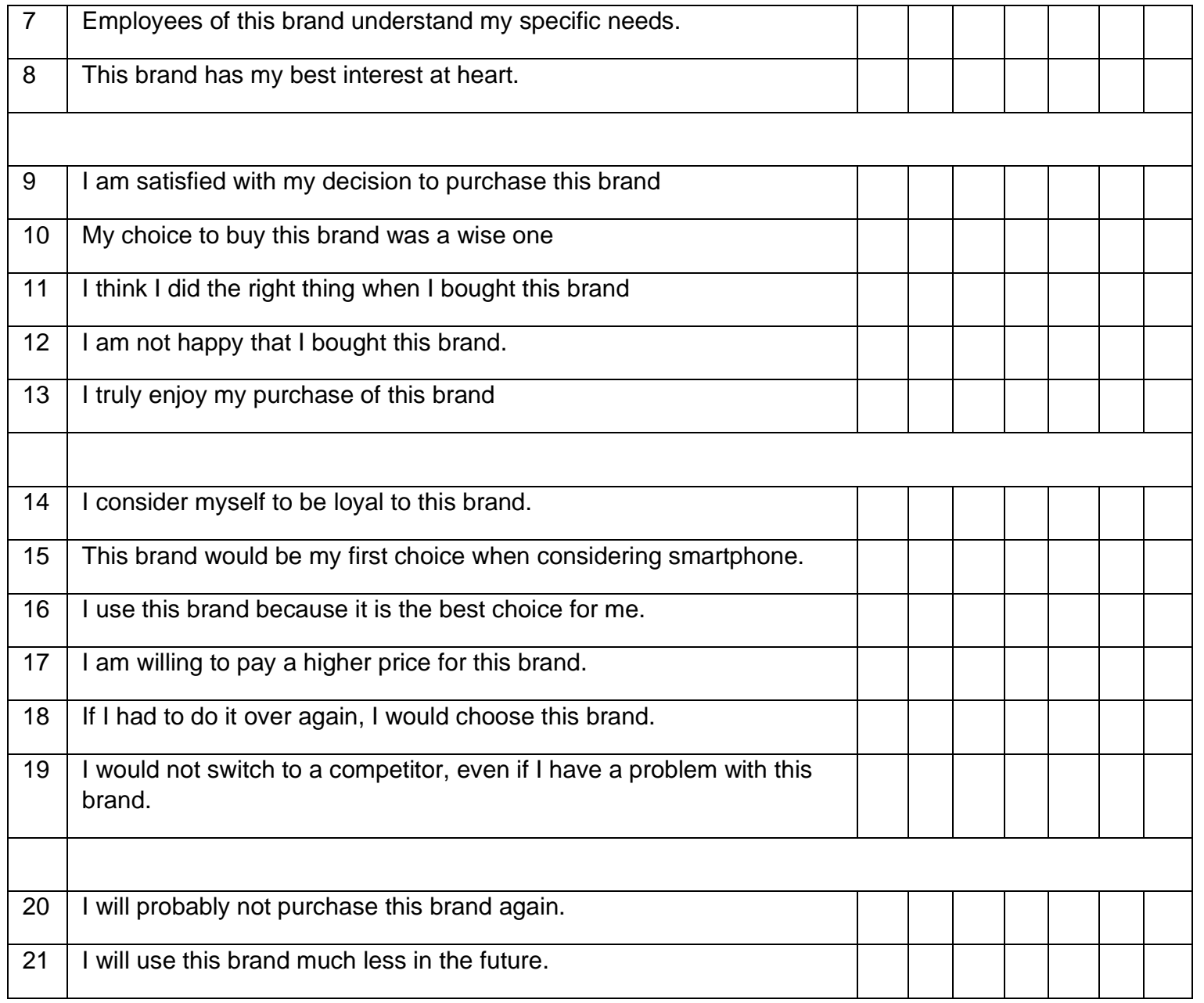

***These questions are extracted from previous studies (Chiou \& Droge, 2006; Davidow, 2003;

Matzler, et al., 2008; Zboja \& Voorhees, 2006)

\section{Section Three}

30. The following questions are for classification purposes. Please check appropriately for each question.
a) Gender:
Female
Male
b) Education level:
Secondary or below
Degree
College
Master or above
c) Individual monthly income level (HK\$):
$\begin{array}{lll}\bigcirc_{\$ 10,000} \text { or below } & \bigcirc_{\$ 10,001-\$ 20,000} & \bigcirc \$ 20,001-\$ 30,000 \\ \$ 30,001-\$ 50,000 & \bigcirc \$ 50,001-\$ 70,000 & \bigcirc \$ 70,001 \text { or above }\end{array}$ 


\section{References}

Agustin, C. \& Singh, J., 2005. Curvilinear effects of consumer loyalty: determinants in relational exchanges. Journal of Marketing Research, 42(1), pp. 96-108. https://doi.org/10.1509/jmkr.42.1.96.56961

Ahmed, I. et al., 2010. Impact of Service Quality on Customer Satisfaction: empirical evidence from telecom sector of Pakistan. Interdisciplinary Journal of Contemporary Research for Business, V1(12), pp. 98-113.

Ahmed, I. et al., 2011. Determinants of the satisfaction and repurchase intentions of users of short messenger services (SMAS): A study in the telecom sector of Pakistan. International Journal of Management, 28(3/1), pp. 763-772.

Akhter, S., 2010. Service attributes satisfaction and actual repurchase behavior: The mediating influence of overall satisfaction and purchase intention. Journal of Consumer Satisfaction, Dissatisfaction and Complaining Behavior, 23, pp. 52-64.

Aydin, S. \& Ozer, G., 2005. The analysis of antecedents of customer loyalty in the Turkis mobile telecommunication market. European Journal of Marketing, 39(7/8), pp. 910-925. https://doi.org/10.1108/03090560510601833

Baron, R. \& Kenny, D., 1986. The moderator-mediator variable distinction in social psychological research: Conceptual, strategic, and statistical considerations. Journal of Personality and Social Psychology, 52(6), pp. 1173-1182. https://doi.org/10.1037/0022-3514.51.6.1173

Chang, P., Chuang, C., Chuang, W. \& Lin, W., 2015. An examination of the effects of quality on customer loyalty: the automobile industry in Taiwan. Total Quality Management, 26(2), pp. 203217. https://doi.org/10.1080/14783363.2012.704268

Chen, C. \& Myagmarsuren, O., 2011. Brand equity, relationship quality, relationship value, and customer loyalty: Evidence from the telecommunications services. Total Quality Management and Business Excellence, 22(9), pp. 957-974. https://doi.org/10.1080/14783363.2011.593872

Chiou, J. \& Droge, C., 2006. Service quality, trust, specific asset investment, and expertise: Direct and indirect effects in a satisfaction-loyalty framework. Journal of the Academy of Marketing Science, 34(4), pp. 613-627. https://doi.org/10.1177/0092070306286934

Coner, A. \& Gungor, M., 2002. Factors affecting customer loyalty in the competitive Turkish metropolitan retail markets. Journal of American Academy of Business, 2(1), pp. 189-195.

Davidow, M., 2003. Have you heard the word? The effect of word of mouth on perceived justice, satisfaction and repurchase intentions following complaint handling. Journal of Consumer Satisfaction, Dissatisfaction and Complaining Behavior, 16, pp. 67-80.

Diallo, M., Diop-Sall, F., Djelassi, S. \& Godefroit-Winkel, D., 2018. How shopping mall service quality affects customer loyalty across developing countries: The moderation of the cultural context. Journal of International Marketing, 26(4), pp. 69-84. https://doi.org/10.1177/1069031X18807473

GfK, November 2011. In Survey: iPhone owners most loyal to brand among mobile users, s.l.: GfK Smartphone Survey. Nurembery, Germany: GfK. Retrived from http://www.digitaltrends.com/mobile/survey-iphone-owners-most-loyal-to-brand-among-mobileusers/.

HKSAR, C. a. S. D., 2019. Women and Men in Hong Kong, Key Statistics, s.l.: Social Statistics Branch, Census and Statistics Department.

Holst, A., 2019a. Global smartphone shipments from 2009 to 2018, s.l.: statista. 
Holst, A., 2019b. Smartphone ownership rate by country 2018, s.l.: statista.

Hong, H. \& Cho, H., 2011. The impact of consumer trust on attitudinal loyalty and purchase intentions in B2C e-marketplaces: intermediary trust vs. seller trust. International Journal of Information Management, 31, pp. 469-479. https://doi.org/10.1016/j.ijinfomgt.2011.02.001

International Data Corporation, Dec 2019. Worldwide Smartphone Forecast Update, 2019-2023: December 2019, s.l.: https://www.idc.com/getdoc.jsp?containerld=US45708819.

International Data Corporation, Jan 13, 2020. World Market for Used Smartphones Forecast to Grow to 332.9 Million Units with a Market Value of \$67 Billion in 2023, s.l.: https://www.idc.com/getdoc.jsp?containerld=prUS45865720.

Kasiri, L., Cheng, K., Sambasivan, M. \& Sidin, S., 2017. Integration of standardization and customization: Impact on service quality, customer satisfaction, and loyalty. Journal of Retailing and Consumer Services, V(35), pp. 91-97. https://doi.org/10.1016/j.jretconser.2016.11.007

Keiningham, T. et al., 2007. The value of different customer satisfaction and loyalty metrics in predicting customer retention, recommendation, and share-of-wallet. Managing Service Quality, 17(4), pp. 361-384. https://doi.org/10.1108/09604520710760526

Lam, S. \& Shankar, V., 2014. Asymmetries in the effects of drivers of brand loyalty between early and late adopters and across technology generations. Journal of Interactive Marketing, pp. 28, 26-42. https://doi.org/10.1016/j.intmar.2013.06.004

Lee, D., Moon, J., Kim, Y. \& Yi, M., 2015. Antecedents and consequences of mobile phone usability: linking simplicity and interactivity to satisfaction, trust, and brand loyalty. Information and Management, 52, pp. 295-304. https://doi.org/10.1016/j.im.2014.12.001

Leonnard, S., 2018. Perceived Service Quality, Perceived Value for Money, Satisfaction and Repurchase Intention: An Evaluation on Private University Services. International Journal of Commerce and Finance, V4(1), pp. 40-51.

Lin, J. \& Liang, H., 2011. The influence of service environments on customer emotion and service outcomes. Management Service Quality, 21(4), pp. 350-372.

https://doi.org/10.1108/09604521111146243

Matzler, K., Grabner-Krauter, S. \& Bidmon, S., 2008. Risk aversion and brand loyalty: the mediating role of brand trust and brand affect.. Journal of Product \& Brand Management, 17(3), pp. 154162. https://doi.org/10.1108/10610420810875070

Min, S., Zhang, X., Kim, N. \& Srivastava, R., 2016. Customer Acquisition and Retention Spending: An Analytical Model and Empirical Investigation in Wireless Telecommunications Markets. Journal of Marketing Research, pp. 728-744. https://doi.org/10.1509/jmr.14.0170

Muhammad, A., Hamad, N. \& Shabir, G., 2014. Impact of brand equity drivers on purchase intention (a quantitative study of smart phone market). International Journal of Innovative Research and Development, 3(5), pp. 388-394.

Narunart, T. \& Panjakajornsak, V., 2019. An empirical analysis of factors affecting customer loyalty to sea freight forwarders in Thailand. Asia-Pacific Social Science Review, 19(3), pp. 128-143.

Ofori, K., Boakye, K. \& Narteh, B., 2018. Factors influencing consumer loyalty towards 3G mobile data service providers: evidence from Ghana. Total Quality Management, 29(5), pp. 580-598. https://doi.org/10.1080/14783363.2016.1219654

Parasuraman, A., Zeithaml, V. \& Berry, L., 1988. SERVQUAL: a multiple-item scale for measuring consumer perceptions of service quality. Journal of Retailing, 64(1), pp. 12-40. 
Prabowo, H., Astuti, W. \& Respati, H., 2020. Effect of Service Quality and Brand Image on Repurchase Intention through Word of Mouth at Budget Hotels Airy Rooms. OpenJournal of Business and Management, 8, pp. 194-207. https://doi.org/10.4236/ojbm.2020.81012

Rauyruen, P. \& Miller, K., 2007. Relationship quality as a predictor of B2B customer loyalty. Journal of Business Research, pp. 60(1), 21-31. https://doi.org/10.1016/j.jbusres.2005.11.006

Russel-Bennett, R., McColl-Kennedy, J. \& Coote, L., 2007. Involvement, satisfaction, and brand loyalty in a small business service setting. Journal of Business Research, 60(12), pp. 1253-1260. https://doi.org/10.1016/j.jbusres.2007.05.001

Sekaran, U. \& Bougie, R., 2019. Research Methods for Business, A Skill Building Approach. s.I.:West Sussex: John Wiley \& Sons Ltd..

Sharma, A. \& Singh, M., 2012. Customers' perceptual analysis of cellular operators in Northern India. Journal of Services Research, 12(1), pp. 131-152.

Shin, D., 2014. Effect of the customer experience on satisfaction with smartphone: assessing smart satisfaction index with partial least squares. Telecommunication Policy. , p. http://dx.doi.org/10.1016/j.telpol.2014.10.001.

Shin, D., 2015. Quality of experience: beyond the user experience of smart services. Total Quality Management, 28(8), pp. 919-932.

Solimun, S. \& Fernandes, A., 2018. The mediation effect of customer satisfaction in relationship between service quality, service orientation and marketing mix strategy to customer loyalty. Journal of Management Development, 37(1), pp. 76-87. https://doi.org/10.1108/JMD-12-20160315

Srivastava, K. \& Sharma, N., 2013. Consumer attitude towards brand extension: A comparative study of fast moving consumer goods, durable goods and services. Journal of Indian Business Research, 5(3), pp. 177-197. https://doi.org/10.1108/JIBR-07-2012-0057

Suhud, U. \& Bajunaid, S., 2018. Satisfied, but will they spread a word? The role of customer satisfaction at Jamu Cafe. Binus Business Review, 9(1), pp. 1-8. https://doi.org/10.21512/bbr.v9i1.3915

Su, J. \& Tong, X., 2016. Brand personality, consumer satisfaction, and loyalty: A perspective from denim jeans brands. Family and Consumer Sciences Research Journal, 44(4), pp. 427-446. https://doi.org/10.1111/fcsr.12171

Tseng, F. \& Lo, H., 2011. Antecedents of consumers' intention to upgrade their mobile phones. Telecommunications Policy, 35(1), pp. 74-86. https://doi.org/10.1016/j.telpol.2010.11.003

Upamannyu, N., Gulati, C., Chack, A. \& Kaur, G., 2015. The effect of customer trust on customer loyalty and repurchase intention: The moderating influence of perceived CSR. International Journal of Research in IT, Management and Engineering, 5(4), pp. 1-31.

Wilson, N., Keni, K. \& Tan, P., 2019. The effect of website design quality and service quality on repurchase intention in the E-commerce industry: A cross-continental analysis. Gadjah Mada International Journal of Business, 21(2), pp. 187-222. https://doi.org/10.22146/gamaijb.33665

Yadav, M. \& Rai, A. K., 2019. An assessment of the mediating effect of customer satisfaction on the relationship between service quality and customer loyalty. The IUP Journal of Marketing Management, 18(3), pp. 7-23.

Zboja, J. \& Voorhees, C., 2006. The impact of brand trust and satisfaction on retailer repurchase intentions. Journal of Services Marketing, 20(5), pp. 381-390.

https://doi.org/10.1108/08876040610691275 